\title{
Midas' gift means death: Tax dodging is the biggest obstacle for global justice
}

\section{Hans Morten Haugen}

Faculty of Theology, Diakonia and Leadership, VID Specialized University hans.morten.haugen@vid.no

DOI: http://dx.doi.org/10.5324/eip.v12i1.1991

(cc)BY BY Attribution 4.0 International License, which permits unrestricted use, distribution, and reproduction in any medium, provided the original author and source are credited.

Tax havens and tax secrecy have risen to the top of the global policy agenda and may constitute the most important impediment for reducing inequalities. Moreover, complex corporate structures allow charging for services undertaken in various countries through one low-tax country. Transferring profits to low-tax jurisdictions will significantly reduce a multinational corporation's overall tax burden. Individuals are assisted in opening shell corporations that officially own bank accounts where the real owner (beneficial owner) is not revealed. Reducing this practice of tax dodging (which encompasses both legal tax avoidance and illegal tax evasion) has proven to be difficult, despite substantial efforts by several international organizations and states over the last decade. It is too easy to be removed from the list of tax havens; mere membership in OECD's Global Forum on Transparency and Exchange of Information for Tax Purposes qualifies. Tax dodgers add to global inequalities and severely weaken states' capacity to undertake their task of creating a solid tax base, embedded in the principle that all actors are taxed according to the income generated in each country. A weak tax base will lead to less trust, more violence and more deaths.

Keywords: country-by-country reporting, EU, OECD, tax avoidance, tax evasion, tax havens

High-profile revelations (LuxLeaks and Panama Papers) prove that a segment of the population in most countries actually lives in a parallel society, removed from the norms that others seek to comply with. Using tax advisors, many of whom work for the "Big Four" accounting firms (Deloite, Ernst \& Young, KPMG, PWC), these individuals do everything possible to enrich themselves rather than contributing to well-functioning states, crucial infrastructure and life-saving services.

People working on tax justice issues were not surprised at these disclosures; on the contrary, these revelations confirm what has been known for a long time. By contrast, both politicians and the CEOs of financial institutions in Western countries appeared surprised. Their surprise is objectively unfounded, as they have had enough information to understand and act for a long time. Interestingly, decision-makers in developing countries and countries in transition rank tax avoidance as the most crucial measure to reduce inequality (UNDP 2013: 210). Two 
other tax-related issues scored lowest (taxing finance) and middle (tax incentives for foreign direct investments), the latter being explicitly warned against in the 2015 Addis Ababa Action Agenda of the Third International Conference on Financing for Development (2015 Addis Ababa; United Nations 2015: paragraph 26).

While inequality was included in the Sustainable Development Goals (SDGs), as SDG 10, the targets and indicators do not refer explicitly to tax, which is probably the most important measure for reduced inequality. The 2015 Addis Ababa does, however, give a broad mandate for "redoubling efforts to substantially reduce illicit financial flows... by combating tax evasion and corruption..." (United Nations 2015: paragraph 23). "Country by country reporting," specifying profits and other information for each country (EU 2016a), and automatic exchange of tax information are all recommended (United Nations 2015: paragraph 27; see also paragraph 29). The United Nations is not, however, the most important international actor; rather the Organization for Economic Cooperation and Development (OECD; United Nations 2015: paragraph 28) and the Financial Action Task Force (FATF; United Nations 2015: paragraph 24) specify states' obligations in greater detail.

Tax dodging is the term applied in this article; it encompasses tax avoidance and tax evasion. Tax dodging is the preferred term, as it is not always initially obvious whether a specific practice is morally dubious tax avoidance or illegal tax evasion. There are various approaches to assess the global amount of tax dodging. OECD holds that up to 10 percent of global corporate income tax revenues are not being paid due to profit shifting to low-tax jurisdictions or tax havens, representing a total loss of up to USD 240 billion annually (OECD 2016: paragraph 68).

This figure is roughly the same as the total income that is lost by individuals' fortunes being hidden from taxes (USD 21 trillion), based on a calculation of an ordinary tax payment at a 3-percent rate of return on this fortune (Tax Justice Network 2012: 2). The Norwegian Commission on Capital Flight from Developing Countries (2009: 64) says that illicit capital flows from developing countries alone totaled USD 641-979 billion annually, referring to Kar and Cartwright-Smith (2008), but the figure used in their final report is actually USD 850-1000 billion (Kar and Cartwright-Smith 2008: vi). Irrespective of this mismatch of figures, they exceed the total Official Development Assistance (ODA) (142 billion USD; OECD 2017) and migrant workers' remittances (USD 595 billion; World Bank 2017) to developing countries. Note that these figures do not include what is lost each year due to corruption, much of which is also ending up in tax havens.

This article proceeds as follows: First, it presents basic justifications for taxation, identifying the tax challenges raised by economic globalization. Second, it identifies the most crucial obstacles for effective tax collection, particularly for transnational corporations. Third, it reviews OECD, Norwegian, EU and US measures. Fourth, it reviews how measures against money laundering and public procurement processes can reduce tax dodging. Next, I identify factors indicating a higher awareness of tax dodging. I conclude by suggesting an ethical approach to tax dodging.

This article seeks to answer the research question: How does the widespread practice of tax dodging contribute to greater global inequalities and weakening of states, and how can tax dodging be effectively combated? 


\section{Basic justifications for taxation}

Taxation has never been popular, but taxes have been crucial for the formation of the modern state system, as well as for democracy. When people pay taxes, they demand influence over how the money is spent. As these demands were gradually addressed, modern parliaments emerged as a result. The slogan "no taxation without representation" came out of the English Revolution (1689), inspiring cries for democracy in other countries in subsequent centuries. Moreover, broad-based taxation creates mutual trust that is decisive for the functioning of state institutions, so that these institutions are inclusive and not extractive, the latter designed by the elites "to extract resources from the rest of the society" (Acemoglu and Robinson 2012: 81).

Given this background, it is easy to agree with U.S. Supreme Court Associate Judge Oliver Wendell Holmes, Jr., who stated in 1904: "Taxes are the price we pay for a civilized society" (IRS (Internal Revenue Service) 2016). The best-functioning states, with the lowest levels of inequalities, are simultaneously the states with the best ability to collect taxes. Taxation raises the awareness of being a part of a larger community, with the overall benefits that this implies. Weak states, faulty infrastructure and poor services are a direct function of inadequate tax collection (Fukuyama 2014; 2011).

This relationship can be illustrated in a positive spiral (from Johnson 2011):

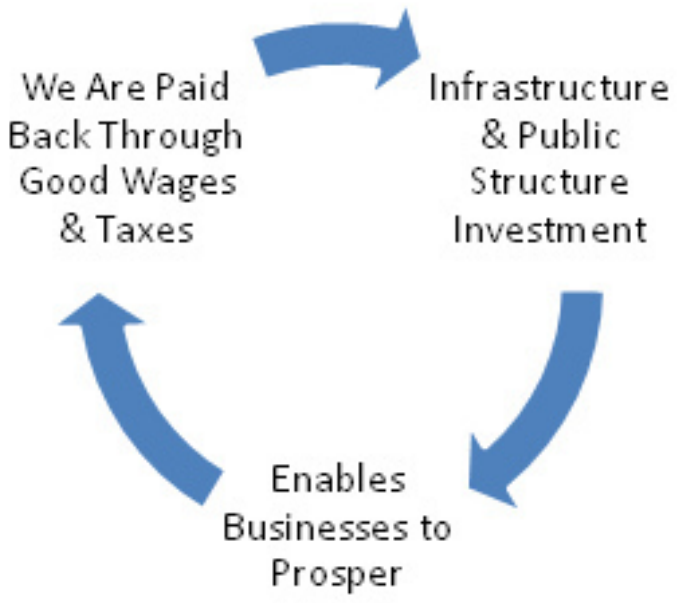

Tax payment, according to this understanding, is embedded in social contract theory, where everyone contributes to the public good, hence enabling public institutions to distribute and invest resources to facilitate and improve the functioning of individuals and enterprises.

Egalitarianists, represented by Wilkinson and Pickett (2009) and Piketty (2014) have presented strong arguments on the importance of distribution through taxation, and particularly Wilkinson and Pickett have been subject to criticism for selectively choosing countries and variables (Snowdon 2010; Saunders 2010; in support of most of the original findings, see Hiilamo and Kangas 2014).

Those who express principled criticism of taxation can come from various ideologies, but the dominant school is libertarianism (Fraser 2000; Rothbard 1982; Nozick 1974). The main argument of all of these critics is that by taxing its citizens, the state is using force to take something that belongs to someone and using it for someone else's purposes. For Nozick this "something" is part of the fruit of one's labor, while for Rothbard it is one's property. Fraser, agreeing with both of them, ends up endorsing anarcho-capitalism (Fraser 2000: 234). The issue of consent is 
crucial for libertarians. Anyone who does not agree with the principle of taxation nevertheless has to obey the duty to pay taxes - as specified and practiced by the majority - with the possibility of punishment for non-compliance.

The task of tax collection becomes more difficult in a globalized economy. The multitude of domiciles of multinational corporations (MNCs) implies that a wide range of bilateral tax treaties have been entered into, primarily with the purpose of avoiding double taxation. A much bigger problem, as will be shown below, is the way MNCs are organized and operate, and how individuals consciously seek to conceal themselves as the real owners ("beneficial owners") of bank accounts.

\section{Crucial obstacles for effective tax collection}

MNCs can choose to locate in low-tax jurisdictions or outright tax havens. The strategies for the two differ. It is therefore necessary to distinguish between the two, the former relating to tax avoidance, and the latter relating to tax evasion.

Low-tax jurisdictions are characterized by low tax rates, and frequently market themselves as such, but are otherwise normally functioning economies. Relevant examples include Ireland and the Netherlands. For an MNC that seeks maximum profit, the more overall income that can be ascribed to these countries, the better. Therefore, taxation is minimized by having all activities that do not depend on a specific location in the low-tax jurisdictions. By charging excessively high prices on these services, only minimal profits are reported in normal-tax jurisdictions where the main part of an MNC's activities take place. This strategy thus substantially reduces the total tax payment by taxing a large part of the total income in low-tax jurisdictions.

The MNC may manage internal services - such as marketing, custom relations, design development and intellectual property - in the low-tax jurisdictions. For example, when Microsoft customers in any country in Europe or the Middle East pay their invoices to the Microsoft office in Luxembourg for all services done by Microsoft employees, a huge gap exists between Microsoft's actual activities in a country like Norway and Microsoft's income as reported to Norwegian tax authorities.

This situation makes it almost impossible for wholly nationally domiciled corporations to compete on fair terms, as their overall tax burden makes them much less profitable compared to an MNC that can shift the payment for many of its services to low-tax jurisdictions.

Tax havens are identified by the Financial Secrecy Index (Tax Justice Network 2018a). The index is composed of 20 secrecy indicators (Tax Justice Network undated), as well as a global scale weight. The top three countries in 2018 are Switzerland, USA and the Cayman Islands.

Tax havens are characterized by secrecy, parallel taxation regimes between nationals and foreigners, and often the prohibition of substantive activities or owning of properties in the tax havens by foreigners. Various tax haven lists exist, but the Financial Secrecy Index shows that not only small island states harbor tax havens.

Tax havens have been the subject of considerable attention over the last decade. Running the risk of being declared a "non-cooperative tax haven" has made them eager to enter into agreements on automatic exchange of tax information with other states. The three last tax havens on the OECD list of non-cooperative tax 
havens were all European: Andorra, Liechtenstein and Monaco. They were removed from this list in 2009.

Some tax havens have specialized in providing services enabling joint financing of investments taking place in other countries. As an example, investments from the Norwegian Norfund, the government's main instrument for combating poverty in developing countries through private sector investments, invest in Eastern African countries through Mauritius. According to Norfund, this makes the investments financially safer, and makes it easier to co-finance with other investors (Bistandsaktuelt 2016; E24 2016). ${ }^{1}$

This, and the fact that the Norwegian Pension Fund and Argentum, a Norwegian government enterprise that holds minority shares in private equity funds, have increased their investments in tax havens, implies that the Norwegian government is indirectly legitimizing tax havens.

Tax havens seek to attract foreign capital as a strategy to improve their nation's own socioeconomic development. Money laundering of incomes originating from criminal and other illegal activities is easy to do through tax havens. Being associated with money laundering not only harms such states' overall reputation, but may make them ineligible for investments. Many governments in tax haven nations are particularly eager to fight money laundering. The FATF, which also has a mandate relating to terror financing, has for the last years listed Iran and North Korea as non-cooperative jurisdictions. Counter-measures against Iran have been suspended since June 2016, but Iran will remain on the FATF Public Statement until the full Action Plan on anti-money laundering and combating the financing of terrorism has been implemented (FATF 2018). Despite the fact than many tax havens actively engage in anti-money-laundering activities, the secrecy that tax havens provide since the real owners are hidden, and "board members" can be chosen from a list provided by the tax haven's authorities - facilitate money laundering.

Important financial centers like Switzerland or the City of London might not be able to know who is actually the real owner of the bank accounts opened in any of their banks. The City of London Corporation is an "autonomous jurisdiction" of 1.22 square miles (Shaxson 2011: 247) for its 9000 inhabitants and 350000 daytime employees, having been a self-governing municipal entity for more than 800 years.

Notwithstanding the differences between the various tax havens, the overall problem is that they allow money to be hidden from domestic tax authorities. This implies that many states are either looted by kleptocrats or depleted of revenues that should have benefited of the inhabitants, as well as the effective working of its institutions.

Abolishing the system of tax havens would not solve the problems of money being taken from one jurisdiction to another for the purpose of reducing tax, but such "tax competition" would be manageable, unlike the current global system of hiding money.

\section{Measures that reveal MNCs' profits and taxes in all jurisdictions - and their inadequacies}

A full review of all possible measures to curb tax dodging is beyond the scope of this article. This section will analyze recent initiatives within country-by-country reporting, where the company must in principle provide information on activities, profits and revenues in all countries where it operates. There are many exceptions to this, as will be seen. 
The OECD has updated its 1992 Model Convention with Respect to Taxes on Income and on Capital ten times since its adoption, most recently in November 2017. The 1998 Multilateral Convention on Mutual Administrative Assistance in Tax Matters was updated in 2010 to improve the exchange of information and so far, more than 100 states participate in the Convention (some have only signed and not ratified). Moreover, OECD oversees the Global Forum on Transparency and Exchange of Information for Tax Purposes with a total of 132 members. Merely being a member implies that a state is not considered a tax haven (Klassekampen 2016). Using a two-phased review, with criteria for information availability, access and exchange, states are placed in five different categories (ranked order): complying, largely complying, partially complying, qualifying, and not qualifying. A map of a state's results in two "rating rounds" is available (OECD 2018). We see that the OECD has extraterritorial influence far beyond its member states.

The OECD's most recent initiative is known by its acronym BEPS (Base Erosion and Profit Shifting). This initiative seeks to avoid the practice of transferring its profits to low-tax jurisdictions. Four of fifteen identified "Actions" address so-called transfer pricing, which are intra-corporation transactions where prices are manipulated with the purpose of dodging taxes. The last BPES Action is to develop a multilateral instrument to modify bilateral tax treaties so that they include BEPS provisions.

Undoubtedly, the OECD has a strong commitment to fighting tax dodging. We saw above that two OECD conventions have occurred since the 1990s. Despite these efforts, the Tax Justice Network calculates that the amount of private wealth kept in tax havens doubled in the years between 2005 and 2010, representing an increase of 16 percent each year (Tax Justice Network 2012: 2). This rapid increase happened even though OECD efforts were widely known, at least among lawyers and tax advisors. Moreover, the exchange of tax information system requires specific identification of given persons. If the tax authorities are to obtain relevant information, it is necessary to reveal the names of the persons suspected of tax dodging.

BEPS Action 13 on country-by-country reporting apparently has a comprehensive scope, requiring annual reports for each tax jurisdiction in which companies do business. The report encompasses revenue, profit before income tax and income tax paid, as well as total employment, capital, retained earnings and tangible assets. However, this information is only required to be provided to tax authorities, implying that the information is not for the public. Moreover, the requirements apply only to MNCs with an annual consolidated (total) revenue of EUR 750 million or more (OECD 2015: 4). Hence, most MNCs are exempted.

These weaknesses are obviously a reflection of the political will among the member states. Norway requires information in line with BEPS Action 13 (Norway $2013, \$ 3$ ) if the corporation has a consolidated revenue of NOK 320 million (USD 40 million), a balance sheet of NOK 160 million (USD 20 million) and at least 250 employees (Norway $2013 \$ 1$; two of three requirements must be met). As we see, the threshold is substantively lower than the EU threshold, but nevertheless rather high. Moreover, the reporting requirement does not apply to jurisdictions in which the MNC's subsidiaries only have "supportive functions" (Norwegian Parliament 2013), which must be understood as tax havens.

While the EU has country-by-country reporting, its requirements were less detailed than those outlined by the OECD, and limited to the extractive industries 
(EU 2013a) and the financial sector (EU 2013b). In the aftermath of the Panama Papers, the EU decided to initiate country-by-country reporting for the whole EU, but only for corporations with an annual turnover of more than EUR 750 million (EU 2016a), similar to the OECD threshold referred to above.

The USA was the first country to require disclosure of payment to all governments, but only to those states where the activities take place. Section 1504 of the Dodd-Frank reform act was challenged by the American Petroleum Institute (The Guardian 2015), and the US Securities and Exchange Commission (SEC) has adopted new provisions, effective from 2016 (US SEC 2016).

Hence, while it is too early to evaluate the BEPS program in each country or on a global level, substantial challenges remain, primarily as regards secrecy.

\section{Further changes? Anti-money laundering and tax specifications in public procurements}

While legislative changes have so far not been able to curb the practice of tax dodging, there are several ways to proceed. These relate primarily to revealing the identities of the real owners of offshore shell companies and require that the overall corporate structure be revealed.

Anti-money laundering efforts seek to prevent money stemming from illegal activities from becoming part of the ordinary economy and thus being impossible to trace. In addition, the EU has since 2004 emphasized non-fulfillment of tax obligations as a justifiable reason to exclude a corporation from public procurement contracts, provided that tax payment obligations are clearly outlined in the tender specification. We will review these two efforts in this order.

Overall efforts to fight money laundering and terrorism financing is most comprehensively regulated in the Fourth directive on money laundering (EU 2015), which applies to financial institutions and credit institutions, as well as auditors, accountants, tax advisors, estate agent and public employees, such as notaries. The strictest requirements are with financial institutions and credit institutions, as specified by Article 19. Financial institutions and credit institutions involved in breaches of the obligations outlined in the Directive that are "serious, repeated, systematic, or a combination thereof" can be subject to pecuniary sanctions of least EUR 5 million or $10 \%$ of the total annual turnover, in accordance with Article 59.3(a).

The main focus of the Directive is "customary due diligence", or knowing who is the actual owner of a property, shell company or bank account. To gain information about the real owners (Article 3.6), a register of such beneficial owners must be established in each state (Article 30.3). While this is not specified in the Directive itself, it is crucial that such a register be open to everyone (Tax Justice Network Norway 2015). Non-governmental organizations, academics and investigative journalists can all provide critical assistance, provided that they have adequate access to information.

This article will identify whether specifying the fulfillment of tax obligations in tenders of public procurements is a possibility, and whether excluding a corporation from public procurement contracts is conceivable. At the core of the analysis is how to comply with EU (and EEA) public procurement obligations.

Already in 2004 the now repealed public procurement directive (EU 2004) specified in Article 45.2(f): 
Any economic operator may be excluded from participation in a contract where that economic operator [...] has not fulfilled obligations relating to the payment of taxes in accordance with the legal provisions of the country in which he is established or with those of the country of the contracting authority.

The crucial term is "obligations." What is required to determine that tax payment obligations have not been fulfilled? The specification that the obligations are either read out from "legal provisions of the country in which he is established or with those of the country

of the contracting authority" makes it relevant to ask when it became a legal obligation to comply with these provisions. Moreover, is the establishment of a complex corporate structure with the purpose of substantively reducing an MNC's tax obligations to be considered as not fulfilling this MNC's legal obligations?

To the first question, one might take a legal positivist approach and say that this is when some given domestic legislation - such as incorporating a country-bycountry reporting requirement and with specific sanctions for inadequate reporting or tax payment - enters into force. One might take another approach, based on the evolving international norms of morality and transparency in tax matters. Since the issue in public procurement is not about punishing law violators, but rather about instilling tendering competitions based on fair terms, it seems as if the legal positivist approach cannot be the only approach. Faced with one or more tenderers who are paying 50 percent less in tax than other tenderers with similar turnovers, this does not represent fair competition, even if such a practice might not be illegal as specified in the legislation.

A related question may help to answer question two above: should a public contractor require an MNC participating in the tender to provide specific information on the corporate structure in different jurisdictions, with as detailed information as is required in the BEPS Action 13's country-by-country reporting requirements and the new EU requirements (EU 2016a)? This is obviously relevant in order for the public contractor to assess whether the tenderer has "fulfilled obligations relating to the payment of taxes."

To answer this question, Article 27.1 in the now repealed Directive 2004/18/EC is interesting. It states that the contracting authority may provide information on "the body or bodies from which a candidate or tenderer may obtain the appropriate information on the obligations relating to taxes." Hence, the tenderer should be assisted in identifying information on obligations relating to taxes.

The new public procurement directive that repealed the 2004 Directive specifies with regard to payment of social security contributions and taxes that "an additional certificate may be required of any registered economic operator whenever a contract is to be awarded" (EU 2014: Article 64.5). Hence, taxation is considered to be a complex kind of information that might require the economic operator or tenderer to provide supplementary information.

We saw that exclusion from public procurement processes was possible under the previous Directive. A similar provision on exclusion is also included in the new Directive (EU 2014: Article 57.2), but only if the contractor "is aware that the economic operator is in breach of its obligations relating to the payment of taxes..." and requiring that "this has been established by a judicial or administrative decision having final and binding effect..." Exclusion can in accordance with the second paragraph of Article 57.2 also take place if such breach can be "demonstrated" by the 
contracting authority. Interestingly, the Norwegian Regulation says that the exclusion from a procurement processes can take place also in the absence of a final judicial or administrative decision, unless such exclusion would be disproportionate (Norwegian Government 2016: $\$ 24-2(3) a)$. The latter requirement ("unless ... disproportionate") was not in the draft Regulation (Norwegian Government 2015: $\S$ 18-2(3)a). By including a "proportionality" requirement, the Norwegian Regulation is more demanding than the EU directive.

The exclusion from public procurement can therefore be considered to be more difficult under the present EU public procurement directive as compared to the previous one.

To be able to "demonstrate" breach of obligations relation to tax payments, public contractors must require the MNC tenderers to provide a full overview of its corporate structure, and request detailed information about each of the MNCs subsidiaries, in line with the requirements of BEPS Action 13. This is possible in accordance with Article 64.5 of the 2014 Directive. It is the level of specificity in the tender announcement, as formulated by the public contractor, that is decisive. It might be difficult for the MNC to provide all the information, or the MNC might actually not want to reveal all the information.

Therefore, the public contractor can specify in the public procurement announcement that it will emphasize the tenderers' overall tax obligations, by requiring that the totality of the corporate structure be revealed, with detailed information for each subsidiary. This can be justified with arguments relating to fair competition. This requirement might cause some potential tenderers to abstain from applying. When seeing the proposals from the different tenderers, the public contractor can determine that the contractor has adequate information or - if the contractor believes that the information is not adequate - ask an MNC tenderer for more information. This is a way that public authorities can promote tax transparency and fight tax dodging.

\section{Greater awareness concerning tax dodging}

While the previous sections have identified the many changes in the law in recent years and clarified how tax justice can be promoted by public contractors, there are real challenges for promoting tax justice and fighting tax dodging globally.

First, many of the tax havens with small economies are highly dependent upon their financial sectors, as they have a non-diversified economy. Second, many tax havens are found in large economies, such as the United Kingdom (City of London) and the USA (Delaware and Nevada). These states also tend to be cautious about pushing for changes that will result in unemployment. Third, economic crimes, with the exception of narcotics financing and terrorist financing, are simply not given the necessary attention. Fourth, the fact that the "Big Four" accounting companies employ some of the world's leading tax advisors and best financial investigators, and simultaneously lead the development of international norms' - particularly the International Financial Reporting Standards and the International Accounting Standards - implies that the states depend on these companies for any progress.

This realistic side of the equation is balanced by other aspects. First, governments express an increasing acknowledgement of the dangers of tax dodging for the survival of welfare states and states' overall performance. The importance of institutions for economic growth is convincingly shown in the Norwegian Commission on Capital Flight from Developing Countries (2009). Moreover, cuts 
in public spending have been shown in an IMF (International Monetary Fund) study to lead to reductions in production in the private sector of one and a half to three times the predicted figure (Blanchard and Leigh 2013). The concerns over payments in publicly financed welfare services - some ending up in tax havens - led the Norwegian Parliament in December 2017 to request the Norwegian Government to establish a public commission to map "money flows" in these services (Norwegian Parliament 2017a: 5).

Second, consumers have hardly started to "vote with their wallet" against tax dodgers. For instance, the practice of Den Norske Bank (DNB) - where the Norwegian state is the main owner - having offices in tax havens has been known for several years. Nevertheless, it has not acted on strong recommendations from the Norwegian government, and its customers have been loyal to the bank. After the Panama Papers revealed that the DNB office in Luxembourg facilitated a private person's establishment of shell companies in the Seychelles for the purpose of not revealing the real owners of bank accounts in Luxembourg, a survey found that 67 per cent had lower trust in DNB (VG 2016). Somewhat surprisingly, the drop in trust was lowest among those aged 18 to 29 .

Third, the development of digital tools will make it easier to exchange information and fight tax dodging. Another aspect of digital development is the increase in digital payments. Reduced use of cash and increasing use of credit cards does correlate with reduced crime rates in the USA (Wright and others 2014). A Norwegian study found that only 37 to 47 percent of cash holdings in Norway could be linked to lawful, registered purposes (Gresvik and Kaloudis 2001; see also Norges Bank 2010). Already in 2002, the OECD predicted that "money's destiny is to become digital" (OECD 2002: 7). Hence, digital payments are good for transparency and preventing tax dodging.

\section{An ethical approach to tax dodging}

As seen above, tax dodging overwhelmingly takes place due to the inadequacies of regulation at national and global levels. Therefore, when discussing tax dodging practices and how to counter them, it is relevant to emphasize measures in the global context. The social contract argument mentioned above can be linked to egalitarianism, but it applies primarily to the national level and not to the global level.

Is there any applicable social contract theory that could be applied to the global level? Cosmopolitanism has presented strong arguments for new global approaches to taxation (Pogge 2014: 77-78; Pogge 2011: 29-30). The crux of cosmopolitanism is that "all human beings, regardless of their political affiliation, are (or can and should be) citizens in a single community" (Stanford Encyclopedia of Philosophy 2013). According to Pogge, by condoning "lax accounting standards" and accepting "illicit deposits" (Pogge 2011: 29), banks and rich states are complicit in harmful tax and embezzlement practices. He states that these entities are not doing enough to change harmful practices by reforming international institutions or by compensating the victims of such practices. As was seen initially, decision-makers in developing countries and countries in transition rank tax avoidance as the most crucial measure for reduced inequality (UNDP 2013: 210).

Other cosmopolitans have emphasized a humanity-based rather than an institutional cosmopolitanism. A review of this line of reasoning concludes that it is "difficult to specify what duties and costs an individual should be expected to bear 
... beyond 'negative' duties not to collaborate with unjust global institutions" (Langford and Darrow 2013: 438). These negative duties apply to individuals who are in charge of tax obligations of corporations for which they work, as well as their own tax obligations.

According to Langford and Darrow, Nobel Laureate in economics Amartya Sen has also presented cosmopolitan thinking, primarily through his book The Idea of Justice (2009). His main argument is that the various forms of cross-border exchange and contacts imply that political considerations cannot be "confined to the citizenry of any given country, ignoring all others" (Sen 2009: 403). Sen, best known for his entitlement theory (Sen 1981) and his theory of development as freedom (Sen 1999), has been widely acclaimed for identifying factors that impede and enhance development prospects on the domestic level, but his cosmopolitan thinking remains "undertheorized," according to Langford and Darrow (2013: 440).

Hence, this brief review shows that while there are legitimate concerns over lack of effective participation and influence in global decision-making, lack of effective sanctions for harmful practices, and lack of compensation, extending the social contract theory to the global level faces real challenges. Langford and Darrow's analysis is embedded in the so-called extraterritorial obligations of states, defined as:

obligations relating to the acts and omissions of a State ... that have effects on the enjoyment of human rights outside of that State's territory; and ... obligations ... to take action, separately, and jointly through international cooperation, to realize human rights universally (Extraterritorial Obligations Consortium 2012: para. 8).

International cooperation and assistance for human rights realization is already recognized in Article 56 of the UN Charter and Article 2.1 of the International Covenant on Economic, Social and Cultural Rights. This definition also identifies acts and omissions with effects outside of the state's territory.

Within the UN human rights system, it is the Special Rapporteur on extreme poverty and human rights who has presented the most comprehensive analysis and recommendations on tax reforms, including cooperating for enhanced transparency and information exchange (UN Special Rapporteur on extreme poverty and human rights 2015, paras. 52-53; UN Special Rapporteur on extreme poverty and human rights 2014). The reports have emphasized domestic tax policies, including potentially harmful tax incentives for companies (UN Special Rapporteur on extreme poverty and human rights 2014: para. 65) and references to states that have adopted taxes on certain types of cross-border financial transactions (UN Special Rapporteur on extreme poverty and human rights 2014: para. 96).

The Special Rapporteur on extreme poverty and human rights has made no specific recommendations on domestically collected taxes for global purposes. Such taxes or levies are termed "innovative sources of finances" or "innovative taxation," and the only such levy currently in operation is the air ticket levy. Eight countries currently charge this levy (Unitaid 2018), which provides half of the funding for Unitaid (2017: 15) that has as its motto "Innovation in global health." A finance tax on shares, bonds and derivatives was set to be introduced in ten EU member states in 2016, but has been postponed. Some EU member states claim that this type of tax must apply to all EU member states (European Parliament 2017; see also Reuters 2017). Interestingly, the United Kingdom, being one of the states expressing the strongest opposition to such a tax, has a long history of taxing the purchase of shares 
through its so-called "stamp tax." While the tax from 2008 only applies to purchases worth GBP1000 or more (UK Government 2014a), it has collected GBP 125.4 billion since 2000 (UK Government 2017).

Turning to the other ideological position raised earlier in this article, namely libertarianism, their main objection is on taxation at the domestic level. Interestingly, libertarianism is also embedded in human rights argumentation, primarily the human right to property and to a fair trial. While selecting a restricted number of human rights to the detriment of other human rights can justifiably be challenged, it is obvious that a well-ordered society needs respect of property and courts, in case contracts are not adequately enforced.

Libertarianist views on reducing the share of the economy that goes through the state for redistribution and investments have been rejected in principle by two of the world's richest people. We will use these individuals as examples in discussing whether tax dodging is an expression of greed.

Warren Buffet pointed out the irony that he and other super-rich individuals in the USA paid less in federal taxes, as a portion of income, as compared to those with ordinary incomes. He therefore called for increased tax payments for the richest in dividuals. This led Barack Obama to propose the so-called "Buffet Rule" as part of a tax plan launched in 2011, setting a 30 percent tax for everyone with more than USD 1 million in annual income. The proposal was stopped in the Senate in 2012 (US Administration 2012). ${ }^{2}$

Bill Gates provides another interesting case. His wealth is partly based on Microsoft's inadequate tax payments. This is possible through Microsoft's overall corporate structure, in which services undertaken in one normal-tax country are charged in a low-tax country, allowing the whole Microsoft consortium to avoid billions of dollars in tax each year. Gates says that "tax systems are the primary thing that asks the most successful to fund the basics that we would like to have for everybody" (Gates 2015; 1:44-1:54), but the interviewer does not challenge him on Microsoft's own tax practices. While Gates has devoted all his time, energy and money to the Bill \& Melinda Gates Foundation since he stepped down as CEO of Microsoft in 2000, his attitude nevertheless does appear hypocritical (The Guardian 2014).

Hence, one can be positive to the need to fund the state in order to enable it to undertake its responsibilities - or in human rights terminology, to fulfill its human rights obligations - but nevertheless be complicit in setting up corporate structures that undermine this very ability of the state.

Such practices of creative corporate structures are increasingly being challenged. The EU Commission found in 2016 that Ireland was violating EU rules on state aid, a decision that Ireland has appealed. By its low tax rate, Ireland has granted undue tax benefits of up to EUR 13 billion to Apple Inc. and must now recover this illegal state aid (EU 2016b). Even the CEOs in the technology companies admit that the tax system is flawed and should be reformed (The Guardian 2018). A new measure to tax digital services - also termed an "equalization levy" - was proposed by the EU in March 2018 and is expected to lead to an estimated EUR 5 billion in revenues (EU 2018). This proposal does not include measures for imposing a "source tax," in other words taxation based on activities and income generated in each country (Norwegian Ministry of Finance 2018; see also Norwegian Parliament 2017b). Such a source tax is a step towards so-called "unitary taxation" or "formulary apportionment" that is promoted by Tax Justice Network (2018b). 
The super-richest individuals, 62 of whom control as much wealth as the poorest 50 percent of the world's population, or 3.6 billion persons (Oxfam 2016), pay very low tax amounts because their capital is hardly taxed. Concentration of wealth is happening rapidly. In 2010, the 382 richest persons' wealth matched that of the world population's poorest half. Some of the super-rich themselves want to be taxed more, like Warren Buffet - as seen above - but politicians prevent such reforms from taking place. Moreover, not all efforts to reduce one's tax burdens are illegitimate. For instance, strategic forms of personal savings that also give tax reductions are fully within the law, but inadequate reporting and information exchange facilitate tax avoidance. Hence, both formally legal tax avoidance and formally illegal tax evasion represent considerable challenges.

The Oxfam Report on global inequalities concludes with five specific recommendations to fight tax havens and end secrecy: agreeing on a UN tax body; ending the practice of tax incentives (UNDP 2013: 210); requiring country-bycountry reports that are publicly available; establishing public registers of corporations' beneficial owners; and creating a multilateral system for automatic exchange of tax information (Oxfam 2016: 34-35).

Not all aspects of these recommendations can be comprehensively assessed, but some critical points will be highlighted. First, when balancing between representativeness and effectiveness, sometimes effectiveness should prevail. An intergovernmental body within the UN might not necessarily be as effective as the OECD has proven to be. To be clear: although the OECD is not adequately effective, the UN might not be similarly effective, but the UN must nevertheless strengthen its work to fight harmful tax dodging.

Second, it is crucial that the financial reports showing tax payments in all jurisdictions and registries of beneficial owners be made publicly available. While the Norwegian publishing of tax payments of all citizens was found to violate the human right to privacy (NRK 2012), one can obtain information on the 100 individuals with highest incomes in each municipality. Such transparency must also apply to companies.

Third, it is important that the exchange of tax-related information should not require tax authorities requiring information to identify the persons, their identity numbers, and their bank account numbers. Easing exchange of tax information without such rigid requirements will make it easier to trace and recover hidden wealth.

Hence, the explanation for the current practices of tax dodging must be sought in more than merely greed. As indicated at the start of the article, recent revelations actually show that a large segment of rich persons and their advisors live in parallel societies. In these parallel societies taxes are not perceived as ethically important. They might distrust "big government" and feel that their own interests are not adequately taken care of. Spending a great deal of time abroad might further contribute to this detachment from complying with one's tax duties. Such practices are exacerbated by legal and institutional inadequacies to counter tax dodging at both national and international levels.

\section{Conclusion}

So how does all this relate to the death aspect of Midas' gift? Midas' desire for riches turned out to be a curse as everything he touched, even his daughter, became gold. This fairytale shows that our material desires might actually harm us. Pursuing greed 
through tax dodging might in the long term harm everyone, as states become less able to function for the benefit of its inhabitants. Strong and efficient states, accountable institutions, and public policies based on the rule of law have been found to be crucial for political order and stability (Fukuyama 2014; 2011). Those involved in economic transactions are especially dependent upon all these factors.

Hence, while the state does not always contribute to effective redistribution and is biased toward the rich, it is still the most effective instrument for overall societal development. The state achieves this through institutions that improve the functioning of the economy and by building the necessary trust, both horizontally between the inhabitants - and vertically - between inhabitants and decision-makers. This is in turn achieved through the adequate payment of taxes. While tax dodging is garnering more attention than ever before, many hurdles must still be overcome for adequate tax payment to take place, as this article articulates.

The inability of the current tax system to prevent the increase in global inequalities, by allowing the super-rich to remain super-rich, is a part of this problem. Tax payments, on the other hand, facilitate crucial services, betterfunctioning institutions, increased trust, greater equality and less potential for violence.

\section{Notes}

${ }^{1}$ Note that E24 applies the term "legitim" above the Fact box; it should instead read "illegitim".

${ }^{2}$ The proposal initially received a majority of 51 votes, but due to filibuster tactics of certain Republicans, it did not receive the 60 votes required.

\section{References}

Acemoglu, D. and J.A. Robinson (2012). Why Nations Fail: The Origin of Power, Prosperity and Poverty, New York: Crown Publishers.

Bistandsaktuelt (2016). Vi bruker ikke skadelige skatteparadiser. Retrieved March 23, 2018 from www.bistandsaktuelt.no/nyheter/2016/vi-bruker-ikke-skadeligeskatteparadiser.

Blanchard, O. and D. Leigh (2013). Growth Forecast Errors and Fiscal Multipliers, IMF Working Paper 13/1. Washington D.C.: IMF. https://doi.org/ $10.3386 /$ w18779

E24 (2016). Her er legitime grunner til å ha penger i skatteparadis (5 April).

EU (2018). European Commission - Press release. Digital Taxation: Commission proposes new measures to ensure that all companies pay fair tax in the EU. Retrieved March 23, 2018 from http://europa.eu/rapid/press-release_IP-182041_en.htm.

EU (2016a). European Commission - Fact Sheet. Introducing public country-bycountry reporting for multinational enterprises. Retrieved March 23, 2018 from http://europa.eu/rapid/press-release_MEMO-16-1351_en.htm.

EU (2016b). European Commission - State aid: Ireland gave illegal tax benefits to Apple worth up to $€ 13$ billion. Retrieved March 23, 2018 from http://europa.eu/rapid/press-release_IP-16-2923_en.htm.

EU (2015). Directive (EU) 2015/849 of the European Parliament and of the Council of 20 May 2015 on the prevention of the use of the financial system for the purposes of money laundering or terrorist financing. 
EU (2014). Directive 2014/24/EU of the European Parliament and of the Council of 26 February 2014 on public procurement.

EU (2013a). Directive 2013/34/EU of the European Parliament and of the Council of 26 June 2013 on the annual financial statements, consolidated financial statements and related reports.

EU (2013b). Directive 2013/36/EU of the European Parliament and of the Council of 26 June 2013 on access to the activity of credit institutions and the prudential supervision of credit institutions and investment firms.

EU (2004). Directive 2004/18/EC of the European Parliament and of the Council on the coordination of procedures for the award of public works contracts, public supply contracts and public service contracts.

European Parliament (2017). Details of EU financial transaction tax ready mid2017, say Council, Commission. Retrieved March 23, 2018 from www.europarl.europa.eu/news/en/press-room/20170118IPR58627/details-ofeu-finan cial-tran saction-tax-ready-mid-2017-say-council-commission.

Extraterritorial Obligations Consortium (2012). Maastricht Principles on Extraterritorial Obligations of States in the Area of Economic, Social and Cultural Rights. Retrieved March 23, 2018 from www.etoconsortium.org/ en/main-navigation/library/maastricht-principles.

FATF (2016). Public Statement 23 February 2018. Retrieved March 23, 2018 from www.fatf-gafi.org/publications/high-riskandnon-cooperativejurisdictions/ documents/public-statement-june-2016.html.

Freser, E. (2000). Taxation, Forced Labor, and Theft. The Independent Review V(2): 219-235.

Fukuyama, F. (2014). Political Order and Political Decay. From the Industrial Revolution to the Globalization of Democracy. London: Profile Books.

Fukuyama, F (2011). The Origins of Political Order. From Prehuman Times to the French Revolution. New York: Farrar, Straus and Giroux.

Gates, B. (2015). Bill Gates on tax, climate and Microsoft. Retrieved March 23, 2018 from http://video.ft.com/4318401597001/Bill-Gates-on-tax-climate-andMicrosoft/Companies.

Gresvik, O. and A. Kaloudis (2001). Økt kontantbeholdning - redusert kontantbruk - Et paradoks? Penger og Kreditt 29(1): 151-156.

Hiilamo, H. and O. Kangas (2014). Cherry picking: How sensitive is the relationship between inequality and social problems to country samples? International Journal of Sociology and Social Policy 34(11/12): 771-792.

IRS (2016). Tax Quotes. Retrieved March 23, 2018 from https://www.irs.gov/uac/Tax-Quotes.

Johnson, D. (2011). Tax Cuts Are Theft. Retrieved March 23, 2018 from www.huffingtonpost.com/dave-johnson/tax-cuts-are-theft_b_675731.html.

Kar, D. and D. Cartwright-Smith (2008). Illicit Financial Flows from Developing Countries 2002-2006. Retrieved March 23, 2018 from www.gfintegrity.org/storage/gfip/economist\%20-\%20final\%20version\%2012-09.pdf.

Klassekampen (2016). Frikjenner skatteparadis (April, 13).

Langford, M. and M. Darrow (2013). Moral Theory, International Law and Global Justice. In Langford, M. Vandenhole, W., Scheinin, M. and van Genugten, W. (Eds.), Global Justice, State Duties. The Extraterritorial Scope of 
Economic, Social, and Cultural Rights in International Law. Cambridge \& New York: Cambridge University Press.

Norges Bank (2010). Vurdering av å fjerne tusenkroneseddelen som ledd $i$ å bekjempe økonomisk kriminalitet. Retrieved March 23, 2018 from https://www.norgesbank.no/Publisert/Brev-og-uttalelser/2010/brev-06-10-2010-3.

Norway (2013). Forskrift om land-for-land-rapportering, FOR-2013-12-20-1682.

Norwegian Commission on Capital Flight from Developing Countries (2009). Tax Havens And Development. Official Norwegian Reports 2009: 19. Retrieved March 23, 2018 from https://www.regjeringen.no/contentassets/0a903cdd09f c423ab21f43c3504f466a/en-gb/pdfs/nou200920090019000en_pdfs.pdf.

Norwegian Government (2016). Ny forskrift om offentlige anskaffelser, No 974, 13 August.

Norwegian Government (2015). Ny forskrift om offentlige anskaffelser. Retrieved March 23, 2018 from https://www.regjeringen.no/contentassets/a20179 ad1beb4de9b4d7f5ccec80c094/horingsnotat-2-forskrift-offentligeanskaffelser.pdf.

Norwegian Ministry of Finance (2018). Dokument 8:69 S (2017-2018) Representantforslag om å utrede en norsk skatt for selskaper med digitale inntektsmodeller - en Google-skatt. Retrieved March 23, 2018 from https://www.regjeringen.no/no/aktuelt/dokument-869-s-2017-2018-

representantforslag-om-a-utrede-en-norsk-skatt-for-selskaper-med-digitaleinntektsmodeller---en-google-skatt/id2587061.

Norwegian Parliament (2017a). Innst. 43 S (2017-2018).

Norwegian Parliament (2017b). Dokument 8:69 S (2017-2018).

Norwegian Parliament (2013). Land-for-land rapportering. Retrieved March 23, 2018 from https://www.stortinget.no/nn/Saker-og-publikasjoner/ Publikasjoner/Innstillingar/Stortinget/2013-2014/inns-201314-004/30.

Nozick, R. (1974). Anarchy, State, and Utopia. New York: Basic.

NRK (2012). Dagfinn (61) med knusende seier mot offentliggjøring av skattelister (April, 10).

OECD (2018). Compare your country. Tax co-operation. Retrieved March 23, 2018 from https://compareyourcountry.org/tax-cooperation.

OECD (2017). Development aid rises again in 2016. Retrieved March 23, 2018 from https://www.oecd.org/dac/financing-sustainable-development/developmentfinance-data/ODA-2016-detailed-summary.pdf.

OECD (2016). BEPS - Frequently Asked Questions. Retrieved March 23, 2018 from http://www.oecd.org/ctp/beps-frequentlyaskedquestions.htm.

OECD (2015). Action 13: Guidance on the Implementation of Transfer Pricing Documentation and Country-by-Country Reporting. Retrieved March 23, 2018 from https://www.oecd.org/ctp/beps-action-13-guidance-implementation-tpdocumentation-cbc-reporting.pdf.

OECD (2002). The Future of Money. Retrieved March 23, 2018 from http://www.oecd.org/sti/futures/35391062.pdf.

Oxfam (2016). An Economy for the 1\%. How privilege and power in the economy drive extreme inequality and how this can be stopped. 210 Oxfam Briefing Paper. Oxford: Oxfam International.

Piketty, T. (2014). Capital in the Twenty-First Century. Cambridge, MA: The Belknap Press of Harvard University Press. https://doi.org/10.4159/ 9780674369542 
Pogge, T. (2014). Are We Violating the Human Rights of the World's Poor? Responses to Four Critics. Yale Human Rights and Development Journal 17(1): 74-87.

Pogge, T. (2011). Are We Violating the Human Rights of the World's Poor? Yale Human Rights and Development Journal 14(2): 1-34.

Reuters (2017). France to push for European financial transactions tax (December, $10)$.

Rothbard, M. N. (1982). The Ethics of Liberty. New York: New York University Press.

Saunders, P. (2010). Beware False Prophets: Equality, the Good Society and The Spirit Level. London: Policy Exchange.

Sen, A. (2009). The Idea of Justice. Cambridge MA: Harvard University Press.

Sen, A. (1999). Development as Freedom. Oxford: Oxford University Press.

Sen, A. (1981). Poverty and Famines: An Essay on Entitlement and. Deprivation. Oxford: Clarendon Press.

Shaxson, N. (2011). Treasure Islands. Tax Havens and the Men who Stole the World. London: The Bodley Head.

Snowden, C. (2010). The Spirit Level Delusion: Fact-checking the Left's New Theory of Everything. Washington, D.C.: Democracy Institute.

Stanford Encyclopedia of Philosophy (2013). Cosmopolitanism. Retrieved March 23, 2018 from http://plato.stanford.edu/entries/cosmopolitanism.

Tax Justice Network (2018a). Financial Secrecy Index - 2018 Results. Retrieved March 23, 2018 from https://www.financialsecrecyindex.com/ introduction/fsi-2018-results.

Tax Justice Network (2018b). ICRICT 'roadmap' for taxing multinationals. Retrieved March 23, 2018 from https://www.taxjustice.net/2018/02/07/icrictroadmap-taxing-multinationals.

Tax Justice Network (2012). Revealed: Global super-rich has at least \$21 trillion hidden in secret tax havens. Retrieved March 23, 2018 from www.taxjustice.net/cms/upload/pdf/The_Price_of_Offshore_Revisited_Presser _120722.pdf.

Tax Justice Network (undated). Secrecy indicators. Retrieved March 23, 2018 from https://www.financialsecrecyindex.com/methodology/secrecy-indicators.

Tax Justice Network Norway (2015). Høring - Økt åpenhet om informasjon om eiere $i$ aksjeselskaper. Høringssvar fra Tax Justice Network - Norge. Retrieved March 23, 2018 from https://www.regjeringen.no/no/dokumenter/horing---oktapenhet-om-informasjon-om-eiere-iaksjeselskaper/id2468940/? uid=b39cebb4-c65f-433f-ad7f-27879823f773.

The Guardian (2018). Google CEO: we're happy to pay more tax (January, 24).

The Guardian (2015). Dodd-Frank's bid to clean up extractive industries stymied by oil Business (July, 22).

The Guardian (2014). Bill Gates preaches the aid gospel, but is he just a hypocrite? (January, 6).

UK Government (2014). Business tax - guidance Stamp Duty on shares. Retrieved March 23, 2018 from https://www.gov.uk/guidance/stamp-duty-on-shares.

UK Government (2014b). United Kingdom (UK) HMRC stamp duty land tax receipts from fiscal year 2000/2001 to fiscal year 2016/2017 (in million GBP). Retrieved March 232018 from https:/www.statista.com/ statistics/284328/stamp-duty-land-tax-united-kingdom-hmrc-tax-receipts. 
UN Special Rapporteur on extreme poverty and human rights (2015). A/HRC/29/31, Report of the Special Rapporteur on extreme poverty and human rights, Philip Alston.

UN Special Rapporteur on extreme poverty and human rights (2014). $A / H R C / 26 / 28$, Report of the Special Rapporteur on extreme poverty and human rights, Magdalena Sepúlveda Carmona.

UNDP (2013). Humanity Divided: Confronting Inequality in Developing Countries. Washington D.C.: United Nations Development Programme.

Unitaid (2018). How We Work. Donors. Retrieved March 23, 2018 from https://unitaid.eu/how-we-work/donors/\#en.

Unitaid (2017). Strategy 2017-2021. Vernier: Unitaid.

United Nations (2015). Addis Ababa Action Agenda of the Third International Conference on Financing for Development, A/CONF.227/20.

US Administration (2012). US Senate Bill S. 2059, Paying a Fair Share Act of 2012.

US SEC (2016). Disclosure of Payments by Resource Extraction Issuers. Retrieved March 23, 2018 from https://www.sec.gov/rules/final/2016/34-78167.pdf.

VG (2016). Tillitsmåling gir kjempesmell for DNB (April, 7). Retrieved March 23, 2018 from www.vg.no/nyheter/innenriks/dnb/tillitsmaaling-gir-kjempesmellfor-dnb/a/23653793.

Wilkinson, R.G. and K. Pickett (2009). The Spirit Level: Why More Equal Societies Almost Always Do Better. London, Allen Lane.

World Bank (2017). Migration and Remittances Data. Retrieved March 23, 2018 from www.worldbank.org/en/topic/migrationremittancesdiasporaissues/brief/ migration-remittances-data.

Wright, R., E. Tekin, V. Topalli, C. McClellan, T. Dickinson, R. Rosenfeld (2014). Less Cash, Less Crime: Evidence from the Electronic Benefit Transfer Program, NBER Working Paper No. 19996. 